УДК: 347.157

Научная статья

DOI 10.18101/2658-4409-2020-3-48-53

\title{
ОСОБЕННОСТИ ПРИМЕНЕНИЯ В ОТНОШЕНИИ НЕСОВЕРШЕННОЛЕТНИХ ПРИНУДИТЕЛЬНЫХ МЕР ВОСПИТАТЕЛЬНОГО ВОЗДЕЙСТВИЯ
}

\section{(C) Самданова Баярма Батоевна}

кандидат юридических наук, старший преподаватель, Бурятский государственный университет имени Доржи Банзарова Россия, 670000, г. Улан-Удэ, ул. Сухэ-Батора, 6 samdan@list.ru

\section{(C) Комарницкая Ольга Сергеевна}

магистрант 2-го курса обучения, Бурятский государственный университет имени Доржи Банзарова Россия, 670000, г. Улан-Удэ, ул. Сухэ-Батора, 6 olkax@mail.ru

Аннотация. В статье на основе изучения судебной практики Железнодорожного районного суда г. Улан-Удэ Республики Бурятия, материалов уголовных дел рассматриваются особенности применения в отношении несовершеннолетних принудительных мер воспитательного воздействия. В своей работе авторы на основе анализа статистических данных подробно рассмотрели варианты применения вышеуказанных мер по уголовным делам в отношении обвиняемых, являющихся несовершеннолетними; раскрыли условия освобождения несовершеннолетних от уголовной ответственности; указали на сложности, возникающие при разрешении вопроса о применении воспитательных мер; выявили основные причины, по котором применение вышеуказанных мер невозможно. Анализируя критерии и условия применения таких мер, они приходят к выводу о том, что от уголовного наказания принудительные меры воспитательного воздействия отличаются тем, что они носят воспитательный характер, не влекут судимости и не рассматриваются как наказание; прямо или косвенно зависят от категории совершенного преступления, возраста несовершеннолетнего лица, количества совершенных им деяний, наличия либо отсутствия судимости, и применение их возможно только в том случае, если судом будет признано, что его исправление может быть достигнуто без уголовного наказания.

Ключевые слова: принудительные меры воспитательного воздействия; несовершеннолетние; освобождение от наказания; освобождение от ответственности; предупреждение; передача под надзор.

\section{Для цитирования}

Самданова Б. Б., Комарницякая О. С. Особенности применения в отношении несовершеннолетних принудительных мер воспитательного воздействия // Вестник Бурятского государственного университета. Юриспруденция. 2020. Вып. 3. С. 48-53.

Преступность несовершеннолетних на данном этапе развития общества имеет тенденцию к стабилизации и определенному снижению в ряде регионов страны, в том числе и в Республике Бурятия, что требует детального анализа и изучения 
Б. Б. Самданова, О. С. Комарницкая. Особенности применения в отношении несовершеннолетних принудительных мер воспитательного воздействия

этого феномена. На заседании Коллегии МВД России по Республике Бурятия по итогам оперативно-служебной деятельности за 2019 г. министр внутренних дел О. Ф. Кудинов отметил, что «почти на $30 \%$ снизилась в регионе подростковая преступность, ее удельный вес уменьшился на $1,6 \%$ и составил $5,6 \%{ }^{1}$.

Так, например, Железнодорожным районным судом г. Улан-Удэ Республики Бурятия за 2019 г. было рассмотрено 50 уголовных дел в отношении несовершеннолетних, что составляет около $5 \%$ общего числа рассмотренных судом дел.

Согласно п. 31 пленума Верховного суда РФ от 1 февраля 2011 г. № 1 «О судебной практике применения законодательства, регламентирующего особенности уголовной ответственности и наказания несовершеннолетних», суды не должны назначать уголовное наказание несовершеннолетним, совершившим преступления небольшой или средней тяжести, если их исправление может быть достигнуто путем применения принудительных мер воспитательного воздействия, предусмотренных ст. 90 УК РФ [3]. Указанное решение пленума Верховного суда РФ отчетливо показывает направление современного вектора развития социальной политики государства в отношении несовершеннолетних. На протяжении последних 10-15 лет правоприменительная и судебная практика отличается приверженностью принципам гуманизма и справедливости в отношении ряда категорий граждан, например, в отношении несовершеннолетних, женщин и лиц, впервые оказавшихся в противоречии с законом. Причем следует заметить, что инициаторами гуманистического подхода выступают не только ученые-юристы, но в первую очередь члены гражданского общества, общественных организаций, представители передовой интеллигенции и рядовые граждане [2, с. $72 ; 4$, с. 81; 5]. Применение к несовершеннолетним принудительных мер воспитательного характера в противовес назначению судами конкретных уголовных наказаний наглядно отражает указанную тенденцию.

Во исполнение указанных норм в Железнодорожном районном суде г. Улан-Удэ Республики Бурятия акценты распределены таким образом, что судьи ориентируются не на назначение наказания, а на освобождение несовершеннолетнего лица от уголовной ответственности и наказания. При этом рассмотрение дел указанной категории поручается специально закрепленным судьям, обладающим наибольшим жизненным опытом и стажем работы.

При рассмотрении в отношении несовершеннолетнего обвиняемого уголовного дела суд может применить принудительные меры воспитательного воздействия в случае вынесения постановления о прекращении уголовного преследования и применении к нему принудительных мер воспитательного воздействия либо постановления обвинительного приговора, назначив ему вместо наказания указанные меры [1, с. 4 ; 3 , с. 62$]$.

Российским уголовным законодательством предусмотрено два варианта прекращения уголовного преследования в отношении несовершеннолетних с применением принудительной меры воспитательного воздействия: на стадии досудебного производства, если органами предварительного расследования будет установлено, что исправление несовершеннолетнего обвиняемого может

1 В МВД по Республике Бурятия состоялось заседание коллегии по итогам работы за 2019 г. URL: https:// https://03.xn--blaew.xn--p1ai/news/item/19329661/ (дата обращения: 09.09.2020). 
быть достигнуто без применения наказания и только по уголовным делам о преступлениях небольшой или средней тяжести ${ }^{1}$; а также при поступлении уголовного дела с обвинительным актом (заключением), суд вправе прекратить уголовное дело и применить к несовершеннолетнему обвиняемому принудительную меру воспитательного воздействия.

Практика применения принудительных мер воспитательного воздействия к несовершеннолетним на примере Железнодорожного районного суда г. Улан-Удэ показывает, что чаще всего принудительные меры применяются судьями в виде освобождения от уголовной ответственности именно по ходатайству органов предварительного расследования. Порядка 74\% изученных судебных решений составляют постановления о назначении принудительных мер воспитательного воздействия, лишь 1\% из них составляют постановления о прекращении уголовного дела с применением воспитательных мер после поступления уголовного дела в суд. В остальных случаях (около 26\%) судом выносятся приговоры, согласно которым несовершеннолетний сначала признается виновным и ему назначается наказание, после чего он освобождается от наказания с применением принудительных мер воспитательного воздействия.

Российское уголовно-процессуальное законодательство определяет, что несовершеннолетнему могут быть назначены принудительные меры воспитательного воздействия в виде предупреждения; передачи его под надзор родителей или лиц, их заменяющих, либо специализированного государственного органа; возложения обязанности загладить причиненный вред; ограничения досуга и установления особых требований к поведению несовершеннолетнего.

Результаты изучения судебной практики Железнодорожного районного суда г. Улан-Удэ Республики Бурятия о применении принудительных мер воспитательного воздействия за период 2018-2020 гг. показали, что чаще всего судом назначается принудительная мера в виде передачи несовершеннолетнего под надзор родителей (законных представителей), поскольку, по мнению суда, эти лица в состоянии обеспечить должный контроль и надлежащее поведение несовершеннолетнего. В тех случаях, когда судом установлено, что вышеуказанные лица не могут должным образом контролировать поведение несовершеннолетнего исходя из анализа характеризующего материала, суд передает его под надзор специализированного органа. Чаще всего в качестве таковых выступают подразделения по делам несовершеннолетних органов внутренних дел (далее - ПДН) или комиссии по делам несовершеннолетних и защите их прав (далее - КДН и ЗП). Как показывает практика, эффективность контроля за такого рода несовершеннолетними напрямую зависит от системного подхода, осуществляемого со стороны субъектов профилактики. В органах внутренних дел подучетный элемент относится к объектам криминального учета информации о таких лицах [6, с. 66]. Ограничение досуга и установление особых требований к поведению несовершеннолетнего, а также предупреждение применяется, как правило, наряду с мерой воспитательного воздействия

\footnotetext{
1 О судебной практике применения судами законодательства, регламентирующего особенности уголовной ответственности и наказания несовершеннолетних: постановление пленума Верховного суда Российской Федерации от 1 февраля 2011 г. № 1. Доступ из справ.-правовой системы «КонсультантПлюс». URL : http://www.consultant.ru/document/ cons_doc_LAW_110315/(дата обращения: 01.09.2020).
} 
в виде передачи под надзор родителей. Такая мера воспитательного воздействия, как возложение обязанности загладить причиненный вред, судом практически не применяется. За рассматриваемый период выявлено всего два случая.

На основе изученных материалов судебной практики установлено, что такая мера, как помещение в специальное учебно-воспитательное учреждение закрытого типа, назначается судьями редко (всего 4\% от общего числа рассмотренных дел). Судьи преимущественно назначают указанную меру в отношении несовершеннолетних, совершивших тяжкие преступления, либо в отношении лиц, ранее судимых, либо к которым ранее уже применялись меры воспитательного воздействия, а также отрицательно характеризующихся, состоящих на учете в комиссиях по делам несовершеннолетних, совершивших несколько преступлений.

Таким образом, принимая решение о назначении мер воспитательного воздействия, судьи руководствуются тем, что совершивший преступление несовершеннолетний может быть исправлен без назначения наказания уголовно-правового характера. При этом практика показывает, что применение указанных мер ставится в прямую зависимость от категории инкриминируемого в вину преступления. Назначая ту или иную меру воспитательного воздействия в отношении несовершеннолетнего, правоприменитель должен подробно изучить характеризующие это лицо данные, условия его жизни и воспитания, отношения в семье, рассмотреть возможность положительного влияния взрослого на несовершеннолетнего.

В связи с этим в Железнодорожном районном суде г. Улан-Удэ Республики Бурятия ведется индивидуальная работа с несовершеннолетними правонарушителями и их законными представителями, составляются карты социальнопсихологического сопровождения на несовершеннолетнего правонарушителя. Обобщенные сведения о подростке в виде карты социального сопровождения предоставляются судье, затем исследуются судом и способствуют принятию наиболее оптимальных и эффективных мер воздействия на подростков, совершивших правонарушения. Вся эта информация о несовершеннолетнем позволяет представить индивидуально-психологические особенности личности подростка, его социальной среды, установить причины и условия, способствовавшие совершению преступлений. Собранные данные, содержащиеся в карте, позволяют суду чаще прекращать уголовное преследование в случае совершения преступлений небольшой и средней тяжести, а также применять принудительные меры воспитательного воздействия и освобождать несовершеннолетних от наказания.

Подводя итоги, можно прийти к следующему выводу: от уголовного наказания принудительные меры воспитательного воздействия отличаются тем, что они носят воспитательный характер. Выражаются они в оказании воздействия на несовершеннолетнего путем убеждений, разъяснений о недопустимости такого поведения в будущем, оценки его проступка, главной задачей являются перевоспитание и социальная адаптация несовершеннолетнего, а цель исправления достигается без привлечения подростка к уголовной ответственности либо без применения уголовного наказания. Принудительный характер таких мер состоит в том, что они применяются независимо от желания подростка либо его законных представителей. Назначаемые судом принудительные меры воспитательного воздействия не влекут судимости и не являются наказанием. 


\section{Литература}

1. Благов Е. В. Об освобождении от уголовной ответственности несовершеннолетних с применением принудительных мер воспитательного воздействия // Юридическая наука. 2017. № 4. С. 4-7.

2. Гантулга Н., Хармаев Ю. В. Опыт влияния трудов русских классиков (Ф. М. Достоевский, А. П. Чехов, С. В. Максимов, В. М. Дорошевич и др.) на гуманизацию пенитенциарной политики в государстве // Преступность в России: проблемы реализации закона и правоприменения: сб. науч. тр. / под ред. В. А. Авдеева. Иркутск: Изд-во БГУЭП, 2015. С. 72-78.

3. Карпов К. Н., Николаев К. Д., Фисенко Д. Ю. Практика применения принудительных мер воспитательного воздействия в отношении несовершеннолетних / К. Н. Карпов // Законодательство и практика. 2016. № 2. С. 62-67.

4. Самданова Б. Б. О некоторых проблемах применения судебного штрафа // Социология уголовного права и реформирование уголовного законодательства: сб. ст. IV Междунар. науч.-практ. конф. Улан-Удэ, 2018. С. 81-87.

5. Филиппова Е. О. Понятие, сущность, цели принудительных мер воспитательного воздействия [Электронный ресурс] // Концепт. 2016. № 3 (март). URL:http://econcept.ru//2016/16051.htm-ISSN (дата обращения: 02.09.2020).

6. Хармаев Ю. В. Теория оперативно-разыскной деятельности: учеб.-метод. пособие. Улан-Удэ: Изд-во ВСГУТУ, 2015. 152 с.

\section{SPECIFIC FEATURES OF THE APPLICATION \\ OF COMPULSORY MEASURES OF EDUCATIONAL INFLUENCE \\ IN RELATION TO MINORS}

Bayarma B. Samdanova

Cand. Sci. (Law), Senior Lecturer,

Dorzhi Banzarov Buryat State University

6 Sukhe-Batora St., Ulan-Ude 670000, Russia

samdan@list.ru

Olga S. Komarnitskaya

$2^{\text {nd }}$ year Master's Student

Dorzhi Banzarov Buryat State University

6 Sukhe-Batora St., Ulan-Ude 670000, Russia

olkax@mail.ru

Abstract. Based on the study of the judicial practice of the Zheleznodorozhny District Court of Ulan-Ude of the Republic of Buryatia, the materials of criminal cases, the article examines the features of the application of compulsory measures of educational influence against minors. In his work, the author, based on the analysis of statistical data, examined in detail the options for applying the above measures in criminal cases in relation to the accused who are minors; disclosed the conditions for the release of minors from criminal liability; pointed out the difficulties arising in resolving the issue of the use of educational measures; identified the main reasons why the application of the above measures is impossible. Analyzing the criteria and conditions for the application of such measures, he comes to the conclusion that coercive measures of educational influence differ from criminal punishment in that they are 
Б. Б. Самданова, О. С. Комарницкая. Особенности применения в отношении несовершеннолетних принудительных мер воспитательного воздействия

educational in nature, do not entail a criminal record and are not considered as punishment; directly or indirectly depend on the category of the crime committed, the age of the minor, the number of acts committed by him, the presence or absence of a criminal record, and their application is possible only if the court recognizes that his correction can be achieved without criminal punishment.

Keywords: accused minors; peculiarities of using compulsory measures of educational influence; termination of criminal prosecution; release of a minor from criminal liability and punishment.

Статья поступила в редакцию 26.09.20; одобрена после редактирования 01.11.20; принята к публикации 05.11.20. 